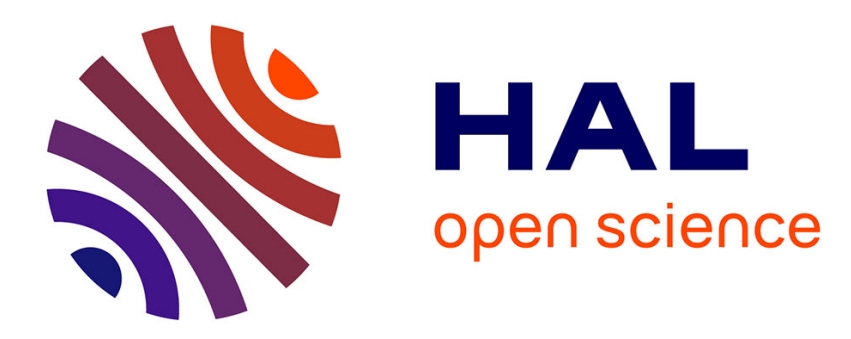

\title{
The Umayyads and the Formation of Islamic Judgeship
}

Mathieu Tillier

\section{To cite this version:}

Mathieu Tillier. The Umayyads and the Formation of Islamic Judgeship. Andrew Marsham. The Umayyad World, Routledge, pp.168-182, 2020, The Umayyad World. halshs-03033241

\section{HAL Id: halshs-03033241 https://shs.hal.science/halshs-03033241}

Submitted on 1 Dec 2020

HAL is a multi-disciplinary open access archive for the deposit and dissemination of scientific research documents, whether they are published or not. The documents may come from teaching and research institutions in France or abroad, or from public or private research centers.
L'archive ouverte pluridisciplinaire HAL, est destinée au dépôt et à la diffusion de documents scientifiques de niveau recherche, publiés ou non, émanant des établissements d'enseignement et de recherche français ou étrangers, des laboratoires publics ou privés. 


\title{
THE UMAYYADS AND THE FORMATION OF ISLAMIC JUDGESHIP
}

\author{
Mathieu Tillier (Université Paris-Sorbonne / UMR 8167 Orient et Méditerranée)
}

According to a statement attributed to the second Abbasid caliph, al-Mansur (r. AH 136158/754-775 CE), the qadi was one of the four pillars of the state. ${ }^{1}$ Islamic judgeship appeared indeed as one of the most emblematic urban institutions of the Abbasids. It was the symbol of a social order based on religious jurisprudence (fiqh) and guaranteed by the government. Yet, the qadi's position at the crossroads of government, religion and society, resulted from an evolution that is still imperfectly known. The history of judicial institutions in Islam has been extensively studied since the mid-twentieth century. Emile Tyan's work remains a major reference on the subject. ${ }^{2}$ However, its principal weaknesses are a certain tendency to generalize from Egyptian examples - Tyan's main source was al-Kindi, and he did not know Waki's book on judges - and too positivist a reading of legal sources. His studies were mainly supplemented by those of Robert Brunschvig and Joseph Schacht, who were particularly interested in the law of evidence. ${ }^{3}$ More recently, Wael Hallaq questioned the role of judges in the formation of Islamic law, ${ }^{4}$ Steven Judd devoted a long chapter to Umayyad qadis and their relationship with rulers, ${ }^{5}$ and Christopher Melchert published an important study on the judicial oath in early Islamic times. ${ }^{6}$

However, Abbasid literary sources used by most historians partially blur our understanding of Umayyad judgeship. Their authors were driven by a quest for authority, and often adopted a teleological approach. That is, when recounting the history of former qadis and reporting cases they adjudicated, they were looking for the roots of the system as it existed in their own time. Therefore, they offer a standardised image of the institution, rarely subject to variations, which makes it difficult to distinguish between a historical nucleus and possible projections on the past. In order to achieve a better understanding of the Umayyad judgeship, we must therefore not only pay attention to any signs of change while rereading literary sources, but also take into account types of sources usually neglected by historians: documentary sources on papyrus, as well as "ancient schools"” legal doctrines preserved in early Abbasid literature, such as 'Abd al-Razzaq al-San'ani and Ibn Abi Shayba's Musannaf-s.

One of the most important challenges of modern research on early Islam is our ability to breech the historiographical filter imposed by Abbasid models, which causes an impression of temporal and geographical uniformity. As for Umayyad judgeship, to what extent is it possible to bring into focus differentiated regional developments of the institution? What dynamics of unification presided over the development of a legal "Islamic" system? This

\footnotetext{
${ }^{1}$ Al-Tabari, Ta'rikh, III/1: 398.

2 Tyan 1960.

${ }^{3}$ Brunschvig 1976.

${ }^{4}$ Hallaq 2005.

5 Judd 2014.

${ }^{6}$ Melchert 2008.
} 
chapter will show that the Umayyad period was a crucial one for the construction of Islamic judgeship, through the gradual establishment of administrative and legal structures that achieved their full development under the Abbasids.

\section{Judges}

Literary sources such as chronicles and biographical dictionaries mention judges called "qadis" from the beginning of the Umayyad period, at the latest. ${ }^{7}$ However, no documentary evidence attests to the existence of these "proto-qadis". ${ }^{8}$ In the current state of research, no Palestinian or Egyptian papyrus, nor any document from Khurasan, throws any direct light on the institution during the first century of Islam. The only hypothetical appearance of the word "qadi" in an Umayyad papyrus dates back to 730 or $740 \mathrm{CE}$, but no judicial role is associated with the bearer of this title. ${ }^{9}$ The documentary absence of the word does not necessarily mean the inexistence of the institution. Available papyrological sources come mainly from the Egyptian countryside, overwhelmingly inhabited by Christian populations, where justice long stayed in the hands of institutions inherited from Byzantium, such as dukes and pagarchs. ${ }^{10}$ Most Muslims were in Fustat, the provincial capital, where very few papyri have been found so far. Therefore, this documentary absence of qadis suggests only that this institution did not exist in secondary towns and rural areas of Egypt. That is not surprising given the low rate of Islamization of the province under the Umayyads.

During the Sufyanid period, as documented by the dossier of Papas, pagarch of Edfu, the main judicial authority in Upper Egypt was apparently the duke of Thebaid, who was based in Antinopolis, assisted by his lieutenant, the topoteretes. Everyday justice was probably dispensed by local pagarchs, at the level of the nome/kura. ${ }^{11}$ In early Marwanid times, Christian pagarchs still acted as judges, as evidenced by governor Qurra b. Sharik's (r. AH 90-96/709-714 CE) letters. A handful of Palestinian papyri, dating back to the late seventh century and discovered in Khirbet el-Mird, suggest that in this part of Bilad al-Sham, justice was rendered by another type of administrator. Although the exact title of these judges is unknown, they may have been a sort of deputy governors and were, for their part, Muslims. ${ }^{12}$ Towards the end of the Umayyad period, justice as documented in Fayyum seems to have been administered by pagarchs (or deputy governors), now Muslims, bearing the title of amir in Coptic literature. Their own deputies may also have dispensed justice at a lower level. ${ }^{13}$

There is little doubt that Muslim judges existed in the provincial capitals of the Umayyad Empire. Did they actually bear the title "qadi" that literary tradition later assigned to them? Fred Donner hypothesizes that this title was created during a process of "qur'anicization" of politico-religious vocabulary, which occurred in the course of the second/eighth century. ${ }^{14}$ This assumption is plausible; however, we can hardly conclude that the function did not exist before that time. Arabic papyri rarely use formal titles during the Umayyad period; for

\footnotetext{
7 Tillier 2009: 68-9.

${ }^{8}$ The expression "proto-qadi" was first used by Hallaq 2005: 34.

${ }^{9}$ P.MuslimState 26.

10 Tillier 2013: 20.

11 Tillier 2013: 21-2.

12 P.Mird 18, 19, 20.

${ }^{13}$ Sijpesteijn 2013: 133.

${ }^{14}$ Donner 2011: 86.
} 
example, Qurra b. Sharik is never referred to as "governor" in his Arabic letters, while his title is mentioned in Greek and Coptic ones. ${ }^{15}$ If the title of "qadi" is a late one, as Donner assumes, its invention suggests an important redefinition of the judge's role and position in the governmental sphere.

In provincial capitals, Muslim judges (for convenience, we will continue calling them "qadis") were usually appointed by governors, who entrusted them with daily judicial administration. ${ }^{16}$ They had jurisdiction over all disputes brought before them by litigants, in civil cases or criminal. However, because any trial before a qadi required a plaintiff and a defendant, "criminal" justice (homicide in particular) probably fell already under the scope of institutions able to carry out investigations, such as the police (shurta).

Joseph Schacht sees these qadis as legal "secretaries" of the governors. ${ }^{17}$ It seems clear, as we shall see later, that Umayyad governors were considered as the higher judicial authority within their provinces, and that qadis were only acting as their deputies. The term "secretary" may nevertheless minimize their role, for it suggests that every new governor, when appointed, designated his personal legal representative. This is not what usually happened. In Egypt, al-Kindi's book on judges shows that some qadis of Fustat retained their positions during the tenure of several governors. This in some cases required an explicit "confirmation" from the incoming governor. ${ }^{18}$ Yet, qadiship already appeared as a separate institution, and its holders were likely to remain in office when the governor was dismissed. ${ }^{19}$

The caliph usually appointed directly the qadi of Damascus, but not those of other cities. ${ }^{20}$ The situation may have changed in the second half of the Umayyad period, for al-Kindi states that several qadis of Fustat were appointed by caliphs 'Umar II (r. AH 99-101/717-720 CE) and Hisham (r. AH 105-125/724-743 CE). ${ }^{21}$ However, this information contrasts with Waki's reports about Hedjaz and Iraq, where no appointment by a caliph appears during the same period. ${ }^{22}$ Furthermore, Steven Judd notes that caliphal selection of Egyptian qadis actually happened in an indirect manner, with the governor as an intermediary. ${ }^{23}$ The interventions of some Umayyad caliphs in Fustat's judgeship were therefore not equivalent to the direct appointments that developed under the Abbasids, and were limited to a short period.

Umayyad qadis received a monthly salary (rizq) from the government: between 10 and 16 dinars in Fustat, and about 100 dirhams in Iraq. ${ }^{24}$ However, they were not professional judges. Although some were appointed twice, such as 'Abd Allah b. 'Abd al-Rahman b. Hujayra in Egypt, ${ }^{25}$ they could not expect to stay long in office. On average, qadis remained in office for

\footnotetext{
${ }^{15}$ See the series of papyri P.Lond. IV in Bell 1911-1928.

16 Judd 2014: 131.

17 Schacht 1964: 25.

18 Al-Kindi, Qudat: 311, 313, 325.

${ }^{19}$ It does not mean that the office of qadi was much more stable than that of governor -26 governors were appointed between 40/661 and 132/750, against 23 qadis during the same period. For a contrary view, see Judd

${ }^{20}$ Judd 2014: 100.

${ }^{21}$ Khoury 1986: 15. Cf. Johansen 1997: 985, 992.

22 Tillier 2014: 177.

${ }^{23}$ Judd 2014: 116.

${ }^{24}$ Al-Qadi 2009: 28.

25 Tillier, in al-Kindi, Histoire: 26.
} 2014: 100. 
four years in Fustat, and for three and a half years in Basra and Kufa. Many were dismissed after a few months, and less than a third managed to stay in office for five years or more.

The few data available on their careers show, to a certain extent, the diversity of their profiles. In Egypt, two qadis from the early Marwanid period also exercised military functions, before or after their time in office. ${ }^{26}$ Others followed careers as civil administrators (as head of taxes administration, ${ }^{27}$ of the public granary, ${ }^{28}$ of the military diwan, ${ }^{29}$ or of the chancery ${ }^{30}$ ) or military ones (police chief, ${ }^{31}$ admiral in the navy ${ }^{32}$ ). Only one, towards the end of the Umayyad period, had already got a foothold in judicial administration, as a scribe, before becoming a qadi. ${ }^{33}$ Yet, he also pursued private (oil trade) and public (chancery) activities. ${ }^{34}$ In Medina, the only two qadis on whose careers we are informed were thereafter appointed governors of the city (under Ibn al-Zubayr and 'Umar II). ${ }^{35}$ In Basra, only one qadi, Iyas b. Mu'awiya, is reported to have held another position in civil administration, as market inspector of Wasit. ${ }^{36}$ Some qadis of Kufa followed a similar career, holding positions in tax administration (or as market inspector), ${ }^{37}$ as head of the public treasury, ${ }^{38}$ or as keeper of the seal (khatam) at the governor's chancery. ${ }^{39}$ Only one of them, at the end of the Umayyad period, had had prior judicial experience, as a qadi's assistant ('awn). ${ }^{40}$ Finally, a certain number of Damascus' qadis also exercised in the army or were subsequently appointed as city governors. ${ }^{41}$ One of them was also employed as head manager of the great mosque. ${ }^{42}$ This limited information suggests that many qadis of the Umayyad period were recruited within the circles of military or civilian administrators. It is, however, impossible to say in what proportions.

Some Umayyad qadis combined simultaneously judgeship and another governmental position. In this regard, Egypt contrasts with other provinces: Nearly half of Fustat judges benefited from such multiple offices. From AH 60/679-80 CE to AH 89/708 CE, a majority of Egyptian qadis were also police chiefs (sahib al-shurta), which made the qadi the second in command after the governor, and potentially his deputy in his absence. ${ }^{43}$ Many were also

${ }^{26}$ Al-Kindi, Qudat: 321,326

${ }^{27}$ Ibn Taghri Birdi, al-Nujum, 1: 92.

${ }^{28}$ Al-Kindi, Qudat: 333.

${ }^{29}$ Al-Kindi, Qudat: 354.

${ }^{30}$ Al-Kindi, Qudat: 356.

${ }^{31}$ Al-Kindi, Qudat: 324.

${ }^{32}$ Al-Kindi, Wulat: 39 ('Abis b. Sa'id).

${ }^{33}$ Tillier 2011: 398.

${ }^{34}$ Al-Kindi, Qudat: $352,356$.

${ }^{35}$ Waki', Akhbar, I: 124, 148.

${ }^{36}$ Waki', Akhbar, II: $353 .^{37}$

${ }^{37}$ Waki', Akhbar, II: 406; Ibn Sa'd, Tabaqat, V: 58.

${ }^{38}$ Waki', $^{6}$ Akhbar, II: 410.

${ }^{39}$ Waki', Akhbar, III: 11.

${ }^{40}$ Waki', Akhbar, III: 22.

${ }^{41}$ Fadala b. 'Ubayd, admiral of the Egyptian navy under Mu'awiya (Ibn 'Asakir, Ta'rikh, 48: 296); alNu'man b. Bashir, governor of Kufa, then Hims, under Mu'awiya (Ibn 'Asakir, Ta'rikh, 62: 111, 114); Bilal b. Abi 1-Darda' (Ibn 'Asakir, Ta'rikh, 10: 523); Numayr b. Aws, governor of Adharbaijan (Ibn 'Asakir, Ta'rikh, 62: 225).

${ }^{42}$ Ibn Tulun, Qudat Dimashq: 5.

${ }^{43}$ Al-Kindi, Qudat: 311, 313, 322, 323, 324, 325, 327. 
official preachers (qass), ${ }^{44}$ and two were placed at the head of the public treasury (bayt al$m a l) .{ }^{45}$ The combination of judgeship and the position of police chief appears as an Egyptian specificity. The only other example during the Umayyad period can be found in Medina during the AD 50s/670s CE. ${ }^{46}$ Almost no case of cumulative offices can be traced in Iraq. The only exceptions are two qadis who were also governors of Basra, the first one under caliph 'Abd al-Malik, ${ }^{47}$ and the second one during the AH 110s/730s CE. ${ }^{48}$ Cumulative offices are also rare in Damascus, where we can only find Fadala b. 'Ubayd Allah, who served as deputy of Mu'awiya (r. AH 41-60/661-680 CE) in his absence. ${ }^{49}$ Steven Judd suggests that such regional differences could be an illusion coming from the sources, for al-Kindi pays more attention than other authors do to these administrative details. ${ }^{50}$ However, insofar as Waki also mentions several cases of multiple offices, Judd's assumption seems fragile. It is more likely that a judge's position was understood differently in each province. Several cities associated judgeship with military functions more easily, and favoured recruitment within administrative circles (Egypt, perhaps Syria), while others selected most of their qadis within scholarly circles (Iraq).

\section{Courts}

During the Umayyad period, a majority of litigants were non-Muslims, and a large proportion of disputes were certainly solved by communal institutions. Alongside dukes and pagarchs, who dispensed justice in Egypt under the theoretical supervision of Muslim authorities, religious courts played a major role in dispute resolution. In Iraq and Palestine, rabbinical courts composed of at least three judges treated disputes between Jews. Among Christians, the judicial system was under the supreme authority of the patriarchs of the various churches, and different levels of the ecclesiastical hierarchy held hearing sessions. ${ }^{51}$ Muslim courts soon began to attract non-Muslims, for their judges' decisions probably appeared as more binding than those of communal courts. ${ }^{52}$ However, they could only be found in provincial capitals, far away from towns and villages where the majority of disputes broke out.

The first Umayyad qadis' practice may have followed more of an imperial model than a Muslim one. Controversies between scholars of the first half of the eighth century suggest that, contrary to what is generally believed, mosques were not considered a judicial space at first. ${ }^{53}$ In Kufa, the mosque did not become the main place of hearings before the $\mathrm{AH}$ 100s/717s CE. At the same time, some qadis of Basra dispensed justice in the market, or on the rahaba (i.e., the central square next to the mosque). The case of Damascus (and to a lesser extent of Medina) is even more significant: Until the first decades of the Abbasid era, qadis

\footnotetext{
${ }^{44}$ Al-Kindi, Qudat: 303, 310 (Sulaym b. 'Itr), 315 ('Abd al-Rahman b. Hujayra), 348 (Khayr b. Nu'aym); Ibn Hajar, Raf': 217 ('Abd al-Rahman b. Salim), 322 (Malik b. Sharahil).

${ }^{45}$ Al-Kindi, Qudat: 317 ('Abd al-Rahman b. Hujayra), 332 ('Abd Allah b. 'Abd al-Rahman b. Hujayra).

${ }^{46}$ Waki', Akhbar, I: 118.

${ }^{47}$ Waki', Akhbar, I: 302.

${ }^{48}$ Al-Tabari, Ta'rikh, II/3: 1593 (Bilal b. Abi Burda).

${ }^{49}$ Ibn 'Asakir, Ta'rikh, 48: 290.

50 Judd 2014: 136.

${ }^{51}$ These courts will not be discussed in the present chapter. See Tillier 2017: 455-533.

${ }^{52}$ Simonsohn 2011: chap. 5-6.

${ }^{53}$ Ibn Abi Shayba, al-Musannaf, 3: 619-20, 7: 485.
} 
held hearings on the rahaba, or near the mosque's gates, but not inside the mosque. ${ }^{54}$ These choices reveal the openness of early qadis' courts. Their justice was for all the people, irrespective of their faith. This openness was nevertheless gradually challenged by scholars, who increasingly saw qadiship as a specifically Muslim institution. Towards the end of the Umayyad period, qadis sat more and more inside the mosque. The admission of non-Muslims at their hearings was no longer accepted by everyone. In Fustat, one of the first options was to organize a "mixed" tribunal: Around AH 120/738 CE, Khayr b. Nu'aym received Muslim litigants inside the mosque, and dhimmis outside, on the front steps. ${ }^{55} \mathrm{~A}$ growing number of jurists held that non-Muslims should be referred to their communal courts whenever their disputes did not involve any Muslim. ${ }^{56}$ The displacement of court hearings into the interior of the mosque, completed under the Abbasids (although some Muslim jurists resisted the idea that justice should be dispensed in the mosque), bears witness to the progressive "Islamization" of the judicial system. Moving away from its early universal vocation, which matched the ideology of the Umayyad imperial government, it depended more and more on Islamic law as shaped by Muslim private scholars.

The qadi of the Abbasid period was not only a judge, but also a property manager who exercised guardianship over minors, prodigal and legally incapable people, controlled pious endowments, and so on. ${ }^{57}$ However, sources have little to say about this aspect of the institution during the Umayyad period. According to the image they convey, the judges' main task was actually to resolve legal disputes. In the AH 70s/690s CE, Fustat's qadi 'Abd alRahman b. Hujayra could make public some people's prodigality, but he did not declare them legally incompetent nor did he manage their properties. ${ }^{58}$ The first traces of such actions appear during the AH 110s/730s CE. ${ }^{59}$ Moreover, it was only in the first decade of the eighth century that a qadi began overseeing the orphans' properties through tribal 'arifs. ${ }^{60}$ Qadis' guardianship over orphans was reinforced some time later by order of caliph 'Umar II. ${ }^{61}$ In the 730s CE, the qadi of Fustat began supervising pious endowments (hubs): al-Kindi explicitly says that Tawba b. Namir was the first to do so. ${ }^{62}$ As for Iraqi qadis, Waki ' does not mention any of their administrative tasks during the Umayyad period. These apparently developed at a later stage: in Basra, under caliph al-Mansur, qadi Sawwar b. 'Abd Allah was the first who "strengthened the office of qadi" by supervising pious endowments (waqfs). ${ }^{63}$

Judiciary staff appeared limited in number. Except for dubious information about Shurayh, a semi-legendary qadi from the early decades of Islam, auxiliary judicial functions do not appear in Kufa before the $720 \mathrm{~s},{ }^{64}$ when a herald (munadi) and undefined assistants ( $a$ 'wan)

${ }^{54}$ Tillier 2017: 182-192.

${ }_{55}^{51}$ Al-Kindi, Qudat: 351. Cf. Ibid.: 390-91.

${ }^{56}$ See 'Abd al-Razzaq, al-Musannaf, 10: 321-2; Fattal 2004: 91-4.

${ }^{57}$ Tyan 1960: 359 sq.

${ }^{58}$ Al-Kindi, Qudat: 319.

${ }^{59}$ Al-Kindi, Qudat: 347.

${ }^{60}$ Al-Kindi, Qudat: 325.

${ }^{61}$ Al-Kindi, Qudat: 339.

${ }^{62}$ Al-Kindi, Qudat: 346.

${ }^{63} \mathrm{Waki}^{6}$, Akhbar, 2: 58.

${ }^{64}$ Steven Judd (2014: 132) suggests that around 700, qadi Abu Burda b. Abi Musa employed Sa'id b. Jubayr as a scribe. However sources simply report that governor al-Hajjaj b. Yusuf "had him sit in audience" with Abu Burda. The exact role of this character therefore remains unknown. Perhaps he was advisor to the qadi, or a form 
are first mentioned. ${ }^{65}$ Only under the last Umayyad did a guard (haras) appear in this city, whose mission was to punish litigants found guilty of contempt of court, ${ }^{66}$ as well as scribes recording the testimonies produced before the qadi. ${ }^{67}$ In Basra, a judiciary staff appears in the late 710 s, with a scribe and a guard. ${ }^{68} \mathrm{~A}$ few mentions of a "chamberlain" (adhin) appear only about Bilal b. Abi Burda, whose judgeship overlapped his time as city governor and police chief. ${ }^{69}$ In Medina, the sources only allude to guards carrying whips, from the turn of the eighth century. ${ }^{70}$ Even in Fustat, on the administration of which we are better informed, the only staff mentioned alongside qadis consists of scribes, attested to for the first time around AH 97/716 CE. ${ }^{71}$ Under the Marwanids, each qadi had apparently a single scribe. ${ }^{72}$ Contrary to Hallaq' assumption, nothing indicates that the qadis of Fustat had a court sheriff before Abbasid times. ${ }^{73}$

Literary sources thus offer contrasted images of courts between one province and another. The judgeship of Medina was apparently more "armed" than others, owing to the presence of a guard standing next to the qadi - an image shared, to a lesser extent, with Basra. Conversely, court security forces seem absent in Fustat - even though many of its first qadis were also police chiefs - whereas the bureaucratic organization seems higher there than elsewhere, perhaps because of the administrative tasks that began to fall on Fustati qadis early on. At any rate, the creation of a "tribunal" including diversified staff who assisted the qadi in his judicial and administrative duties was a slow process. There are no reliable textual indications suggesting that, until the 700s or 710s, qadis had any employees at their disposal. In the early eighth century, judicial auxiliaries were still few in number. A qadi could mainly count on a secretary, and sometimes on a guard responsible for maintaining court order.

It is indeed doubtful that Umayyad courts were ever highly bureaucratised. Qadis certainly resorted to writing and preserved documents at home - at least from the 700 s in Fustat. $^{74}$ However, al-Kindi does not allude to actual "archives" (diwan) before AH 118/736 CE. ${ }^{75} \mathrm{Al}$ Kindi and Waki' state unanimously that judgeship experienced an authentic bureaucratic shift during the early decades of the Abbasid period, in Iraq as well as in Egypt: From then on, qadis developed systematic recording of documents and extensive archival practices that did not exist under the Umayyads. ${ }^{76}$

\section{Procedures}

of bicephalous judgeship may have been experimented (cf. Tillier 2009: 281-4). See Waki`, Akhbar, 2: 407, 411; Ibn 'Asakir, Ta'rikh, 26: 56.

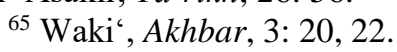

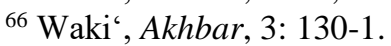

${ }^{67}$ Waki', Akhbar, 3: 136.

${ }^{68}$ Previous mentions of a guard are related to a "qadi" that was first and foremost a governor, Abu Musa alAsh'ari. Waki', Akhbar, 1: 285-6. Voir Waki', Akhbar, 1: 318, 336; 2: 8 .

${ }^{69}$ Waki', Akhbar, 2: 37, $41 .^{\circ}$

${ }^{70}$ Waki', Akhbar, 1: 145, 158, 173.

${ }^{71}$ Ibn Hajar, Raf': 215. See a list of these scribes in Tillier 2011.

72 Al-Kindi (Akhbar: 340) mentions "Yahya b. Maymun's scribes". However, this qadi stayed in office for more than 8 years, and he probably changed scribe during this period.

${ }^{73}$ See al-Kindi, Qudat: 460. Cf. Hallaq 2005: 60.

${ }^{74}$ Al-Kindi, Qudat: 325.

75 Al-Kindi, Qudat: 346.

${ }^{76}$ Waki‘, Akhbar, 2: 58; al-Kindi, Qudat: 379. Cf. Ibn Hajar, Raf $^{\prime} 438$. 
The Umayyad period was a time of experimentations and debates, before court procedures were stabilised within the framework of the classical legal schools of the Abbasid period. Some structures were in place at an early stage: The qadi was a single judge, whose role was to preside over an accusatorial process. He waited to be seized by litigants and did not act exofficio. He based his judgment on evidence that, as in later Islamic law, primarily included confession, testimony and oath. However, the use of such evidence was the subject of discussions and experiments that give Umayyad judicial practices an archaic flavour. ${ }^{77}$

Proofs were not systematically distributed between litigants according to their role (i.e., plaintiff or defendant). In classical Islamic law, the procedure follows the maxim "the double testimonial evidence (bayyina) lies upon the one who makes the allegation, and the oath (yamin) belongs to him who denies". At the beginning of Marwanid times, however, any litigant could bring witnesses to support his statement. Moreover, testimony was not limited to the two honourable witnesses of the classical bayyina. In Kufa, Basra, and Fustat, the testimony of a single witness could have evidential value. In cities such as Basra, Medina, Damascus and Fustat, the party that produced more witnesses than his adversary was likely to win the case. Accordingly, an equal number of witnesses might block the procedure. One of the first questions asked by Muslims at the turn of the eighth century was, therefore, how to manage problems caused by the overabundance of testimonies. ${ }^{78}$ Different solutions were proposed. In Medina and Fustat, the winner of a trial could be determined by drawing lots. In Kufa, however, and perhaps also in Damascus, presumptions (especially the possession of the disputed object) were taken into consideration at an early stage.

Testimonial practices underwent important changes in the first half of the eighth century. From the $700 \mathrm{~s}$ or the $710 \mathrm{~s}$, double testimony appeared as the ideal proof, bayyina. The restrictive use of this type of evidence might have first developed in Kufa, then spread throughout the Muslim East. At the same time, a form of evidence combining testimony and oath begins be mentioned in the sources: the al-yamin ma'a l-shahid procedure, which allowed a claimant to complete the testimony of a single witness with an oath. This method, which had perhaps appeared in Medina in the second half of the seventh century, was adopted in Basra, Damascus and Fustat. ${ }^{79}$ However, except in Medina, this procedure may have been admitted only for a transitional period. It was abandoned in Damascus as well as in Basra by the end of the Umayyad period or during the early Abbasid. It survived some time in Fustat, but was only accepted in the Medinese school and its heirs (the Maliki and Shafi'i schools, and later the Isma'ili and Imami legal doctrines).

The oath was used in different ways. In Marwanid Kufa, a claimant was sometimes required to take an oath after he had produced a witness. An oath could also be administered to both the plaintiff and the defendant. Some Basrian qadis demanded that the witnesses swear they were telling the truth. The double oath of the plaintiff and the defendant was also accepted in Basra. The results of this procedure were unconvincing, however, and in Basra as in Medina, the oath tended to be confined to the defendant. The most obvious tentative of rationalization occurred in Kufa, during the second quarter of the eighth century. First, the claimant had to produce the bayyina, while the defendant was invited to take an oath. Second,

\footnotetext{
${ }^{77}$ The following developments synthesize the conclusions of Chapter 3 of my book L'invention du qadi.

78 'Abd al-Razzaq, Musannaf, 8: 277-8.

${ }^{79}$ For a different opinion, see Melchert 2008: 325.
} 
these two kinds of evidence were not of equal value: The bayyina outweighed the oath. This procedure was assimilated, in Kufa, to "David's judgment", and called fasl al-khitab (literally "termination of the discourse"), an expression that is associated in the Qur'an to the justice of this prophet.

This procedure, which restricted the role of the qadi to reviewing legal evidence provided by litigants, was unanimously adopted by the classical legal schools. It contrasted another perception of justice, especially popular in Basra during the early eighth century. Several qadis, including the famous Iyas b. Mu'awiya under caliph 'Umar II, earned their reputation by looking for material clues. This inquisitorial procedure was based on a specific method, called firasa. The term originally evoked physiognomy as practiced among pre-Islamic Arabs. In the judicial field, it pointed more generally to a qadi's ability to infer truth from circumstantial evidence. In Basra, this method was associated with another Qur'anic concept: that of fahm, or "discernment", associated with the figure of Solomon. This Solomonic procedure put the qadi in the position of a real investigator. Maybe because it could not apply to any type of case, or because it might drift towards a more arbitrary kind of justice, it was eventually abandoned in favour of the "David's judgment".

Documentary evidence was abandoned early. Towards the end of the Umayyad period, alZuhri (d. AH 124/742 CE) still remembered a bygone era when documents could be used as evidence in their own right. Recording the testimony of disappeared persons, they replaced somehow their spoken word and perpetuated it beyond death. ${ }^{80} \mathrm{~A}$ few reports suggest that written documents had a probative value in the eyes of early qadis, especially in Iraq. As early as the 710s at the latest, documents could nevertheless no longer be used as full evidence. They were thenceforth to be confirmed by other legal means: first by an oath, and, increasingly, by the oral testimony of witnesses.

These changes can usually not be dated accurately. What is noticeable, however, is that the Umayyad period was that of an experimental construction of judgeship, along lines that cross regional entities. The disqualification of documentary evidence seems one of the most ancient features of the Islamic legal system, which obliged qadis to refocus the search for judicial truth on witnesses and oaths. For a long time, procedures remained fluctuating from one city to another, and kept changing according to debates between scholars who looked for the best way to distinguish right from wrong. In the second half of the Marwanid period, Kufa seems to have played a prominent role in the rationalization of these methods and the development of the classical accusatorial procedure. This discursive dynamics was also characterised by a progressive alignment of the proof system with a qur'anic rhetoric that placed the judicial process under the aegis of two main prophetic models of justice, those of Solomon and David. These two characters were not only religious referents, though. They were, also, kings and models of government. Indeed, the construction of the legal system depended to a large extent on Umayyad caliphal policy.

\section{Justice and Umayyad government}

Governors were at the top of the provincial judicial hierarchy and had themselves judicial powers. In early Umayyad Iraq, general literary sources - i.e., not focused on qadis - present

\footnotetext{
80 'Abd al-Razzaq, Musannaf, 8: 354-5.
} 
governor Ziyad b. Abihi as the main judge of the province. ${ }^{81}$ Governors are mainly pictured as deciding major cases, involving other government officials ${ }^{82}$ or related to criminal justice, ${ }^{83}$ but daily disputes between individuals were also brought before them. ${ }^{84}$ In the early eighth century, a governor of Basra complained that, although he had appointed a judge, many litigants still appealed to his justice and waited at his door. ${ }^{85}$ In Ansab al-ashraf's volumes devoted to the Umayyad period, most cited trials were conducted before a governor. ${ }^{86}$

Under the Sufyanids, extant papyrological documentation does not say to what extent the Egyptian governor intervened outside Fustat. In the dossier of Papas, pagarch of Edfu under Mu'awiya, the duke of Thebaid appears as the principal judicial authority. The situation is different under the Marwanids. In his letters to Basilios, pagarch of Ishquh/Aphrodito, governor Qurra b. Sharik claimed to have an effective judicial authority. He was solicited by Christian litigants through a procedure that probably prolonged Byzantine practices, and regularly sent rescripts to pagarchs, ordering them to hear their complaints. The governor indicated that evidence (bayyina) needed to be produced by claimants, and specified conditional judgements to be given by pagarchs. ${ }^{87}$

At the top level, Umayyad caliphs also exercised judicial power. In narrative sources, they mainly appear in cases of offenses against state security by heretics or rebels. ${ }^{88}$ However, caliphal justice went beyond these exceptional cases. Mu'awiya sat every morning in the mosque, turning his back to the maqsura, sitting on a chair or throne (kursi) and surrounded by guards, and received complaints of the weak and oppressed people. He judged some of these disputes himself and referred other ones to deputy judges. ${ }^{89}$ The sources also keep track of the judicial activity of several Marwanid caliphs, including 'Abd al-Malik, ${ }^{90}$ al-Walid I (r. AH 86-96/705-715 CE), ${ }^{91}$ Yazid b. 'Abd al-Malik (r. AH 101-105/720-723 CE), ${ }^{92}$ and of course 'Umar II (r. AH 99-101/717-720 CE). ${ }^{93}$ Al-Baladhuri describes the latter as presiding over a court that later historiography assimilated to mazalim - the "injustices" or "spoliations" that, by synecdoche, came to designate a specific court for redress of grievances. ${ }^{94}$

Umayyad caliphs played an important part in the shaping of procedures. Marwan $b$. Hakam's position regarding the testimony of underage boys, the oath and the qasama (collective oath in homicide cases) served as a reference, ${ }^{95}$ as well as 'Abd al-Malik's practice

\footnotetext{
${ }^{81}$ Al-Baladhuri, Ansab (Orient-Institut), 4a: 205, 205-6; al-Baladhuri, Ansab (Zakkar and Zirikli), $11: 115$.

${ }^{82}$ Al-Baladhuri, Ansab (Orient-Institut), 2 : 614, 617-8; 4a: 132-3.

${ }^{83}$ Al-Baladhuri, Ansab (Zakkar and Zirikli), 8: 158; 9: 250.

${ }^{84}$ Al-Baladhuri, Ansab (Zakkar and Zirikli), 9: 360.

${ }^{85}$ Al-Baladhuri, Ansab (Zakkar and Zirikli), 8: 206.

${ }^{86}$ Research carried on on the database al-Maktaba al-shamila (version 3.48, https://shamela.ws/) on 16 April

2013, by a systematic search of the verbs khasama, takhașama, ikhtasama, naza 'a, tanaza' $a$.

87 Tillier 2015: 145-6.

${ }^{88}$ Judd 2014b: 54.

${ }^{89}$ Al-Mas'udi, Muruj, 3: 220-1; al-Baladhuri, Ansab (Orient-Institut), 4a: 109, 283; 5: 275-276; al-Baladhuri, Ansab (Zakkar and Zirikli), 7: 405. See also Crone and Hinds 1986: 44.

90 'Abd al-Razzaq, Musannaf, 6: 251, 286, 499, 519; 9: 146, 188.

91 'Abd al-Razzaq, Musannaf, 5: 307; 10: 161; al-Baladhuri, Ansab (Orient-Institut), 3: 77-78.

92 'Abd al-Razzaq, Musannaf, 10: 45, 240.

${ }^{93}$ Ibn 'Abd al-Hakam, Sira: 102-103, 129-130.

${ }^{94}$ Al-Baladhuri, Ansab (Zakkar and Zirikli), 8: 173, 191.

95 'Abd al-Razzaq, Musannaf, 8: 279, 337, 351; 10: 36; Ibn Hazm, Muhalla, 9: 421; Malik b. Anas, Muwatta' (Shaybani), 3: 290. Cf. Schacht 1950: 193.
} 
in talion cases. ${ }^{96}$ Moreover, as his governors wrote to their pagarchs, the caliph sent judicial rescripts to his judges, with instructions regarding procedures, legal rules and sometimes conditional judgements. The first traces of caliphal rescripts appear with 'Abd Allah b. alZubayr's letters to qadis of Kufa, during the second fitna. ${ }^{97}$ Until the end of the Umayyad period at least, caliphs continued shaping procedures by sending rescripts. Sources preserve examples regarding 'Abd al-Malik, ${ }^{98}$ al-Walid, ${ }^{99}$ Sulayman, ${ }^{100}$ 'Umar II, ${ }^{101}$ Yazid II, ${ }^{102}$ Hisham $^{103}$ and Marwan II. ${ }^{104}$ Syriac sources also emphasize the role of Yazid II in establishing penalties and procedures. ${ }^{105}$

These interventions occurred either after a litigant had complained before the caliph, ${ }^{106}$ or in response to requests sent by the judges themselves. The example of 'Umar II, whose judicial instructions are best documented, suggests that the addressees of these rescripts were mainly governors, either to guide them in the context of a trial they presided over, ${ }^{107}$ or to forward their instructions to their qadis. Caliphal rescripts were sent to various provinces, where they may have been made public; in this way, they probably contributed to the harmonization of legal procedures at an imperial scale. For instance, 'Umar II's letters may have played a major role in the promotion of a legal system based on a strict repartition of proofs between litigants - double testimony produced by the plaintiff, oath taken by the defendant. ${ }^{108}$

Caliphal jurisprudence was not, however, the only driving force in the formation of judicial procedures. The word of the sovereign, even if it appeared as authoritative to many Muslims, was integrated into discussions between scholars. Some of these distanced themselves from caliphal opinions, and dialogic interactions between jurists and qadis, within each province or across the Islamic world, played a major role in shaping the classical model of judicial organization.

The central position of governors in judicial administration is symptomatic of a deep connection between justice and political power under the Umayyads. Qadis could be dismissed at any time, which happened whenever their judicial practice did not please the ruler. In everyday life, they certainly enjoyed a certain latitude to decide on litigations. However, unlike what Judd argued, ${ }^{109}$ a qadi was not independent, neither in theory nor in practice. The rules he was asked to apply were partly issued by the political power, and he

\footnotetext{
${ }^{96}$ Malik, al-Muwatta' (Yahya b. Yahya), 2: 444.

${ }^{97}$ Waki', Akhbar, 2: 321, 404, 405. For more details, see Tillier 2014: 160.

98 'Abd al-Razzaq, Musannaf, 3: 326; 8: 411; 10: 282; Waki', Akhbar, 2: 267.

${ }^{99} \mathrm{Ibn}$ 'Asakir, Ta'rikh, 53: 164-165.

100 Al-Baladhuri, Ansab (Zakkar and Zirikli), 8: 150.

101 Tillier 2014: 168-170.

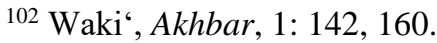

${ }^{103}$ Al-Baladhuri, Ansab (Zakkar and Zirikli), 8: 425; Waki‘, Akhbar, 3: 205; al-Kindi, Qudat: 348.

${ }^{104}$ Al-Baladhuri, Ansab (Zakkar and Zirikli), 9: 250.

${ }^{105} \mathrm{He}$ is supposed to have determined that blood-money for a Christian was half that of a Muslim. Regarding procedures, it is said that he forbade the testimony of a Christian against a Muslim. J.-B. Chabot (ed.), Chronique: 20/18. Michael the Syrian attributes this last ruling to caliph 'Umar II. Michel le Syrien, Chronique,

${ }^{106}$ See for example Ibn 'Abd al-Hakam, Sira: 53-54.

${ }^{107}$ See al-Tabari, Ta'rikh, II.3: 1364-1365.

${ }^{108}$ Ibn 'Abd al-Hakam, Sira: 55.

109 Judd 2014: 102.
} 2: 489. 
Mathieu Tillier, «The Umayyads and the Formation of Islamic Judgeship », in Andrew Marsham (ed.), The Umayyad World, London, Routledge, 2020, p. 168-182.

could be subjected to the delegating authority's direct intervention whenever a lawsuit threatened the latter's interests.

\section{Conclusion}

Umayyad qadis were only one category of actors in a multifaceted imperial legal system. Traditional judicial authorities inherited by the Arab-Muslim conquerors probably dealt with a majority of trials. Rabbinical and ecclesiastical courts were still recognised, as they had been under the Byzantines and the Sassanids. In Sufyanid Egypt, justice was largely in the hands of pagarchs, who were themselves under the authority of dukes. The role of the latter vanished during the early eighth century, to the benefit of the provincial governor. In his correspondence, Qurra b. Sharik appears as the main guarantor of justice. "Qadis" were certainly appointed after the conquests to dispense justice in garrison-cities that soon became provincial capitals. They were acting on the authority of governors, who were themselves appointed by the caliph. In practice, this system was administered in a decentralised manner. Most of the time, governors freely designated their qadis, and until the first half of the eighth century, pagarchs were drawn from local elites inherited from Byzantium. Nevertheless, each level of the administrative structure had theoretical authority on the lower one. The main expression of this authority were rescripts sent to lower courts, carrying instructions about procedures and legal rules that applied to specific cases. The caliph appeared as the supreme judicial authority, who could prescribe the law and send instructions to his governors and their qadis.

The qadi's as well as the pagarch's offices were part of an imperial judicial system that was not primarily a religious one. In the early eighth century, governor Qurra b. Sharik tried to provide his Christian pagarchs' courts with a Qur'anic reference framework. However, it took another decade or two before these pagarchs were replaced by Muslim ones. Qadis were certainly Muslims, but several clues suggest that their hearings were not specifically designed for their co-religionists, for they were held for a long time in the open air, outside mosques. It was only towards the end of the Umayyad period that the mosques emerged as a privileged setting for qadial courts. The rules qadis applied were definitely based on Islamic principles, considered as such because they derived from the Qur'an or the reflection of pious Muslims. Nevertheless, Islamic law was still in its empirical infancy, and its implementation was subject to experimentations, in particular with regard to the procedures.

The formation of legal procedures followed different dynamics. These resulted, to a large extent, from discursive interactions between Muslims themselves. Qadis and scholars from various cities debated the best strategies to discriminate between the truth and falsehood in disputes between individuals. To these interactions, which took place between scholars of the same town, of neighbouring cities or of adjacent provinces, was added the voice of higher political authorities, that of the caliphs and probably of governors. These exchanges contributed to the harmonization of judicial practices and gave birth, at the beginning of the Abbasid period, to a lasting model of Islamic judgeship.

The impact of local traditions and ancient non-Muslim cultures on the formation of Islamic judgeship still needs to be assessed. Surviving sources, however, do not allow for a precise reconstruction of qadis' justice during the first decades of Islam. Because of the historical mist covering Islamic judgeship until around $700 \mathrm{CE}$, a satisfactory explanation of the 
Mathieu Tillier, «The Umayyads and the Formation of Islamic Judgeship », in Andrew Marsham (ed.), The Umayyad World, London, Routledge, 2020, p. 168-182.

relationship between the conqueror's system and those of the Byzantines, Sassanids and preIslamic Arabs cannot be given. As observed in Marwanid times, Islamic judgeship shows commonalities and differences with both imperial systems, and no neat regional distinction can be found. However, it can easily be distinguished from Arab pre-Islamic practices such as they appear in later Islamic reports. Finally, it seems that some judicial experimentations of the Umayyad period can be explained by interactions between Muslim and non-Muslim courts. Some of these already had strong theoretical foundations before Islam (as the Jews), while others developed their legal theory at the same time as Muslims (East-Syrian and WestSyrian churches). ${ }^{110}$

The last two decades of the Umayyad period were characterised by the emergence of a model of judgeship that could be more easily identified as Muslim, and whose functioning was better regulated by the emerging Islamic law. Judicial practices were still far from being fully harmonised, as evidenced by Ibn al-Muqaffa's Risala fi l-sahaba. ${ }^{111}$ Nevertheless, the evolution that started under the Umayyads was confirmed under the Abbasids, with caliph alMansur strengthening the judiciary by detaching it from governors and placing it under his direct authority. ${ }^{112}$ At about the same time, the emergence of a written legal literature in circles of jurists (Maliki and Hanafi) promoted by the Abbasids completed the transformation of qadiship into a leading religious institution.

\section{Bibliography}

NB: Papyrological abbreviations follow the Checklist of Arabic Documents: http://www.naher-osten.lmu.de/isapchecklist

\section{Sources}

'Abd al-Razzaq al-San'ani (1983) Musannaf 'Abd al-Razzaq, ed. Habib al-Rahman alA'zami, Beirut: al-Maktab al-islami.

al-Baladhuri (1996) Ansab al-ashraf, ed. Suhayl Zakkar and Riyad Zirikli, Beirut: Dar al-fikr. - (2008-) Ansab al-ashraf, Beirut: Orient-Institut Beirut-Mu'assasat al-Bayan.

Chabot, Jean-Baptiste (ed.) (1895) Chronique de Denys de Tell-Mahré. Quatrième Partie, Paris: Librairie Émile Bouillon.

Ibn 'Abd al-Hakam (1966) Sirat 'Umar b. 'Abd al-'Aziz, ed. Ahmad 'Ubayd, Damascus?: Maktabat Wahba.

Ibn Abi Shayba (2004) al-Musannaf, ed. Hamad b. 'Abd Allah al-Jum'a and Muhammad b. Ibrahim al-Luhaydan, Riyad: Maktabat al-rushd.

Ibn 'Asakir (1995) Ta'rikh madinat Dimashq, ed. 'Umar b. Gharama al-'Amrawi, Beirut: Dar al-fikr.

Ibn Hajar al-'Asqalani (1998) Raf' al-isr 'an qudat Misr, ed. 'Ali Muhammad 'Umar, Cairo: Maktabat al-Khanji.

\footnotetext{
${ }^{110}$ See Tillier, L'invention du qadi, chap. 6.

${ }^{111} \mathrm{Ibn}$ al-Muqaffa', Risala fi l-sahaba: 42-3. See Tillier 2009: 92-5.

112 Tillier 2009: $101 s q$.
} 
Mathieu Tillier, «The Umayyads and the Formation of Islamic Judgeship », in Andrew Marsham (ed.), The Umayyad World, London, Routledge, 2020, p. 168-182.

Ibn Hazm (1352 H.) Muhalla, Cairo: Idarat al-tiba'a al-muniriyya.

Ibn al-Muqaffa' (1976), Risala fi l-sahaba, in Charles Pellat, Ibn al-Muqaffa' (mort vers 140/757) "conseilleur” du calife, Paris: Maisonneuve et Larose.

Ibn Sa'd (1968), al-Tabaqat al-kubra, Beirut: Dar Sadir.

Ibn Taghri Birdi (1929-1972) al-Nujum al-zahira fi muluk Misr wa-l-Qahira, Cairo: Dar alkutub al-misriyya.

Ibn Tulun (1956) Qudat Dimashq. Al-Thaghr al-bassam fi dhikr man wulliya qada' al-Sham, ed. Salah al-Din al-Munajjid, Damascus: al-Majma' al-'ilmi al-'arabi.

al-Kindi (1912) Qudat = Akhbar qudat Misr, in The Governors and Judges of Egypt, ed. R. Guest, Leiden: Brill. French trans. al-Kindi (2012), Histoire des cadis égyptiens, trans. Mathieu Tillier, Cairo: Ifao.

- Wulat = Ta'rikh Misr wa-wulati-ha, in The Governors and Judges of Egypt, ed. R. Guest, Leiden: Brill.

Malik b. Anas (1991) Muwatta' al-imam Malik (riwayat Muhammad b. al-Hasan alShaybani), ed. Taqi al-Din al-Nadwi, Damascus: Dar al-qalam.

Malik b. Anas (1997) Muwatta' al-imam Malik (riwayat Yahya b. Yahya al-Laythi), ed. Bashshar 'Awwad Ma'ruf, Beirut: Dar al-Gharb al-islami.

al-Mas'udi (1970) Muruj al-dhahab wa-ma'adin al-jawhar, ed. Charles Pellat, Beirut: Publications de l'Université Libanaise.

Michel le Syrien (1899-1910), Chronique, ed. and French trans. by Jean-Baptiste Chabot, Paris: E. Leroux.

al-Tabari (1885-1889) Ta'rikh al-rusul wa-l-muluk, ed. M.J. de Goeje, Leiden: E.J. Brill.

Waki' (1947-1950) Akhbar al-qudat, ed. 'Abd al-'Aziz Mustafa al-Maraghi, Cairo: Matba'at al-sa'ada.

\section{Studies}

Bell, H.I. (1911-1928) “Translations of the Greek Aphrodito Papyri in the British Museum”, Parts I-VI, Der Islam, 2: 269-283, 372-384 ; 3: 132-140, 369-373 ; 4: 87-93; 17: 4-8.

Brunschvig, Robert (1976) "Le système de la preuve en droit musulman", in Études d'islamologie, Paris: Maisonneuve et Larose, II: 201-218.

Crone, Patricia, and Hinds, Martin (1986), God's Caliph. Religious Authority in the First Centuries of Islam, Cambridge: Cambridge University Press.

Donner, Fred M. (2011) "Qur'ânicization of Religio-Political Discourse in the Umayyad Period”, Revue des Mondes Musulmans et de la Méditerranée, 129: 79-92.

Fattal Antoine (2004) "How Dhimmis were Judged in the Islamic World", in R. Hoyland (ed.), Muslims and Others in Early Islamic Society, Aldershot: Ashgate: 83-102.

Hallaq, Wael B. (2005) The Origins and Evolution of Islamic Law, Cambridge: Cambridge University Press.

Johansen, Baber (1997) "Wahrheit und Geltungsanspruch : zur Begründung und Begrenzung der Autorität des Qadi-Urteils im islamischen Recht", in O. Capitani et alii (éd.), La Giustizia nell'alto medioevo (secoli $I X$-XI), Spoleto: Centro italiano di studi sull'alto medioevo: 975-1074.

Judd, Steven (2014) Religious Scholars and the Umayyads. Piety-Minded Supporters of the Marwanid Caliphate, Abingdon: Routledge. 
Mathieu Tillier, «The Umayyads and the Formation of Islamic Judgeship », in Andrew Marsham (ed.), The Umayyad World, London, Routledge, 2020, p. 168-182.

- (2014b) "The Jurisdictional Limits of Qạḍ̄ Courts during the Umayyad Period", Bulletin d'Études Orientales, 63:41-56.

Khoury, Raif G. (1986) 'Abd Allah Ibn Lahi'a (97-174/715-790): juge et grand maître de l'école égyptienne, Wiesbaden: Otto Harrassowitz.

Melchert, Christopher (2008) "The History of the Judicial Oath in Islamic Law", in M.-Fr. Auzépy and G. Saint-Guillain (ed.) Oralité et lien social au Moyen Âge (Occident, Byzance, Islam) : parole donnée, foi jurée, serment, Paris: AACHCByz : 309-326.

Al-Qadi, Wadad (2009), "The Salaries of Judges in Early Islam: The Evidence of the Documentary and Literary Sources", Journal of Near Eastern Studies, 68, p. 9-30.

Schacht, Joseph (1950) The Origins of Muhammadan Jurisprudence, Oxford: Clarendon Press.

- (1964) An Introduction to Islamic Law, Oxford: Clarendon Press.

Sijpesteijn, Petra M. (2013) Shaping a Muslim State. The World of a Mid-Eighth-Century Egyptian Official, Oxford: Oxford University Press.

Simonsohn, Uriel I. (2011) A Common Justice. The Legal Allegiances of Christians and Jews Under Early Islam, Philadelphia: University of Pennsylvania Press.

Tillier, Mathieu (2009) Les cadis d'Iraq et l'État abbasside (132/750-334/945), Damascus: Presses de l'Ifpo.

- (2011) "Scribes et enquêteurs. Note sur le personnel judiciaire en Égypte aux quatre premiers siècles de l'hégire", Journal of the Economic and Social History of the Orient, 54: 370-404.

- (2013) 'Du pagarque au cadi : ruptures et continuités dans l'administration judiciaire de la Haute-Égypte ( $\mathrm{I}^{\mathrm{er}}-\mathrm{III} / \mathrm{e} / \mathrm{VI}^{\mathrm{e}}-\mathrm{IX}{ }^{\mathrm{e}}$ siècle)", Médiévales, 64: 19-36.

- (2014) "Califes, émirs et cadis : le droit califal et l'articulation de l'autorité judiciaire à l'époque umayyade", Bulletin d'Études Orientales, 63:147-190.

- (2015) "Dispensing Justice in a Minority Context: the Judicial Administration of Upper Egypt under Muslim Rule in the Early Eighth Century" », in Robert G. Hoyland (ed.) The Late Antique World of Early Islam: Muslims among Jews and Christians in the East Mediterranean, Princeton: Darwin Press: 133-156.

- (2016) Rendre la justice aux deux premiers siècles de l'Islam.

- (forthcoming) "Local Tradition and Imperial Legal Policy in Umayyad Fustạaț: The Evolution of the Early Egyptian Legal School", in J. Bruning et al. (éd.), Incorporating Egypt: From Constantinople to Baghdad, 500-1000 CE, Cambridge: Cambridge University Press.

Tyan, Émile (1960) Histoire de l'organisation judiciaire en pays d'Islam, Leiden: Brill. 